\title{
Studi Longitudinal Pada Analisis Data Gula Darah Pasien Diabetes melalui Principal Component Analysis
}

\author{
Anna Islamiyati1 ${ }^{*}$, Sitti Sahriman ${ }^{2}$, Sakinah Oktoni ${ }^{3}$ \\ 1,2,3 Departemen Statistika, Fakultas MIPA, Universitas Hasanuddin, \\ Kampus Unhas Tamalanrea Jl. Perintis Kemerdekaan Km. 10, Makassar 90245, Indonesia \\ *Penulis Korespondensi. Email: annaislamiyati@unhas.ac.id
}

\begin{abstract}
ABSTRAK
Multikolinearitas merupakan hubungan atau korelasi antar variabel prediktor. Multikolineritas juga dapat terjadi pada data longitudinal yaitu gabungan dari data cross section dan data time series. Adapun dampak dari multikolinearitas menyebabkan pengaruh variabel prediktor terhadap variabel respon menjadi tidak signifikan, estimator kuadrat terkecil, dan error menjadi sensitif terhadap perubahan dalam data. Oleh karena itu, prosedur untuk mengatasi multikolinearitas, yaitu menggunakan metode principal component analysis. Penelitian ini bertujuan untuk memodelkan regresi data longitudinal PCA dengan model efek tetap yang diterapkan pada data gula darah pasien diabetes dengan rentang waktu Januari 2019 hingga Juli 2019 di Rumah Sakit Ibnu Sina Kota Makassar. Hasil penelitian ini menunjukkan bahwa ada dua komponen utama yang terbentuk dari pemodelan regresi data longitudinal PCA dengan model efek tetap. Diperoleh nilai variabel yaitu tekanan darah sistolik $\left(X_{1}\right)$ sebesar $-0,007$, tekanan darah diastolik $\left(X_{2}\right)$ sebesar $-0,016$, suhu tubuh $\left(X_{3}\right)$ sebesar $-0,098$, dan trombosit $\left(X_{4}\right)$ sebesar 0,005 yang mempengaruhi gula darah pasien diabetes.
\end{abstract}

Kata Kunci:

Multikolinearitas; Data Longitudinal; Principal Component Analysis; Data Diabetes; Model Efek Tetap

\section{ABSTRACT}

Multicollinearity is a relationship or correlation between predictor variables. Multicollinearity can also occur in longitudinal data, which is a combination of cross-section data and time-series data. The impact of multicollinearity causes the influence of the predictor variable on the response variable to be insignificant, the least-squares estimator, and the error to be sensitive to changes in the data. Therefore, the procedure to overcome multicollinearity uses the principal component analysis method. This study aims to model PCA longitudinal data regression with a fixed-effect model that is applied to blood sugar data of diabetic patients with a time span of January 2019 to July 2019 at Ibnu Sina Hospital Makassar City. The results of this study indicate that there are two main components formed from PCA longitudinal data regression modelling with a fixed-effect model. Obtained variable values are systolic blood pressure $\left(X_{1}\right)$ of -0.007 , diastolic blood pressure $\left(X_{2}\right)$ of $-0,016$, body temperature $\left(X_{3}\right)$ of -0.098 , and platelets $\left(X_{4}\right)$ of 0.005 which affect blood sugar in patients with diabetes.

Keywords:

Multicollinearity; Longitudinal Data; Principal Component Analysis; Diabetes Data; Fixed Effect Model

e-ISSN: 2656-1344 (C) 2022 A. Islamiyati, S. Sahriman, S. Oktoni | Under the license CC BY-NC 4.0

Received: 21 August 2021 | Accepted: 11 October 2021 | Online: 1 January 2022 
Format Sitasi:

A. Islamiyati, S. Sahriman, and S. Oktoni, "Studi Longitudinal Pada Analisis Data Gula Darah Pasien Diabetes melalui Principal Component Analysis," Jambura J. Math., vol. 4, no. 1, pp.41-49, 2022, doi: https://doi.org/10.34312/jjom.v4i1.11407

\section{Pendahuluan}

Diabetes adalah penyakit yang erat kaitannya dengan asupan makanan. Asupan makanan seperti karbohidrat atau gula, protein, lemak, dan energi yang berlebihan dapat menjadi faktor risiko awal kejadian diabetes. Penyerapan gula menyebabkan peningkatan kadar gula darah dan mendorong peningkatan sekresi hormon insulin untuk mengontrol kenaikan kadar gula darah diatas batas normal [1]. Internasional Diabetes Federation (IDF) telah mengidentifikasi 10 negara dengan jumlah penderita tertinggi. Cina, India, dan Amerika Serikat menempati urutan tiga teratas dengan jumlah penderita 116,4 juta, 77 juta, dan 31 juta. Indonesia memiliki angka kejadian diabetes yang cukup tinggi berada di peringkat ke-7 diantara 10 negara dengan jumlah penderita sebesar 10,7 juta [2].

Diabetes merupakan penyebab kematian terbesar nomor 3 di Indonesia dengan persentase sebesar $6,7 \%$ setelah penyakit stroke sebesar $21,1 \%$ dan penyakit jantung koroner sebesar 12,9\%. Prevalensi diabetes berdasarkan diagnosis dokter di Sulawesi Selatan pada tahun 2018 sebanyak 50.127 kasus. Kota makassar merupakan salah satu daerah tertinggi dengan angka kejadian penderita diabetes sebanyak 8.611 kasus [3]. Penyakit diabetes terkait dengan kadar gula darah seseorang yaitu gula darah puasa [4], gula darah acak [5], dan gula darah 2 jam setelah makan [6]. Penderita diabetes yang semakin bertambah disebabkan karena kematian akibat penyakit infeksi, pola makan yang salah, kurangnya aktivitas fisik, dan faktor-faktor lain yang diduga mempengaruhi. Oleh karena itu, untuk mengetahui faktor-faktor yang dapat mempengaruhi meningkatnya penderita diabetes, maka dilakukan pemodelan dengan menggunakan analisis regresi.

Analisis regresi digunakan untuk menjelaskan hubungan antara variabel respon dengan satu atau lebih variabel prediktor. Salah satu asumsi yang terdapat dalam analisis regresi linear adalah tidak terdapat multikolinearitas [7]. Multikolinearitas adalah hubungan atau korelasi antar variabel prediktor [8]. Ada beberapa cara yang dapat digunakan untuk mengatasi multikolinearitas, seperti menghilangkan satu atau beberapa variabel prediktor yang memiliki korelasi tinggi, menggunakan partial least square, dan metode principal component analysis [8]. PCA bertujuan untuk mereduksi dimensi data asal melalui transformasi variabel prediktor asal ke variabel prediktor baru yang tidak berkorelasi tetapi tetap mempertahankan keragaman data asalnya [7].

Beberapa penelitian yang telah menggunakan PCA diantaranya Gresyea et.al [9] menggunakan PCA pada analisis regresi linear berganda. Van et.al [10] menggunakan PCA untuk mereduksi faktor-faktor inflasi di Kota Ambon. Selanjutnya, Safaat dan Ully [11] menggunakan PCA untuk pengelompokan area pelayanan dan jaringan daerah Jawa Tengah dan Yogyakarta. Akan tetapi, semua penelitian tersebut menggunakan data cross section. Namun masalah multikolinearitas juga dapat terjadi pada data longitudinal. Menurut Peter et.al [12] mengatakan bahwa data longitudinal merupakan data yang dikumpulkan pada satu waktu tertentu dengan beberapa objek amatan yang terdiri dari beberapa periode waktu. 
Model regresi data longitudinal yang umumnya digunakan terdapat tiga macam yaitu model efek umum, model efek tetap, dan model efek acak. Pemodelan data longitudinal yang dilakukan melalui model efek tetap mengasumsikan bahwa intersep berbeda-beda untuk setiap individu (unit crosss section) tetapi koefisien regresi masing-masing variabel adalah konstan. Muhammad dan Bambang [13] menggunakan pemodelan fixed effect pada regresi data longitudinal dengan estimasi generalized method of moments. Pada penelitian tersebut, peneliti belum mempertimbangkan masalah multikolinearitas yang dapat terjadi pada data longitudinal. Berdasarkan uraian tersebut, dalam penelitian ini masalah multikolinearitas akan diperhatikan dengan menggunakan metode PCA untuk memodelkan regresi data longitudinal PCA dengan model efek tetap yang diterapkan pada data pasien diabetes.

\section{Metode}

Pada penelitian ini, data yang digunakan dalam penelitian ini adalah data pasien diabetes sebanyak 30 pasien dengan rentang waktu 6 kali pengukuran setiap pasien terhitung sejak Januari 2019 sampai Juli 2019 di Rumah Sakit Ibnu Sina Kota Makassar. Variabel yang digunakan terdiri dari gula darah $(Y)$ sebagai variabel respon dan tekanan darah sistolik $\left(X_{1}\right)$, tekanan darah distolik $\left(X_{2}\right)$, suhu tubuh $\left(X_{3}\right)$, dan trombosit $\left(X_{4}\right)$ sebagai variabel prediktor. Pada panelitian ini diawali dengan analisis deskriptif yang bertujuan untuk memberikan gambaran mengenai karakteristik data. Kemudian melakukan uji multikolinearitas dengan melihat hubungan atau korelasi antar variabel prediktor, apabila terdapat multikolinearitas maka untuk mengatasi masalah tersebut digunakan metode principal component analysis. Setelah masalah multikolinearitas teratasi, selanjutnya dimodelkan menggunakan regresi data longitudinal PCA dengan model efek tetap. Langkah terakhir adalah menarik kesimpulan berdasarkan hasil penelitian yang didapatkan.

\subsection{Data Longitudinal}

Data longitudinal merupakan data yang menggambarkan hubungan antara subyek penelitian terhadap waktu [12]. Struktur data longitudinal dapat ditunjukkan pada Tabel 1.

Tabel 1. Struktur data longitudinal

\begin{tabular}{ccccccc} 
Subyek $(i)$ & Waktu $(j)$ & $\begin{array}{c}\text { Variabel } \\
\left(Y_{i j}\right)\end{array}$ & $\begin{array}{c}\text { Variabel } \\
\left(X_{i j 1}\right)\end{array}$ & $\begin{array}{c}\text { Variabel } \\
\left(X_{i j 2}\right)\end{array}$ & $\ldots$ & $\begin{array}{c}\text { Variabel } \\
\left(X_{i j p}\right)\end{array}$ \\
\hline \multirow{3}{*}{ Subyek 1 } & 1 & $Y_{11}$ & $X_{111}$ & $X_{112}$ & $\cdots$ & $X_{11 p}$ \\
& 2 & $Y_{12}$ & $X_{121}$ & $X_{122}$ & $\cdots$ & $X_{12 p}$ \\
& $\vdots$ & $\vdots$ & $\vdots$ & $\vdots$ & $\ldots$ & $\vdots$ \\
$\vdots$ & $m_{1}$ & $Y_{1 m_{1}}$ & $X_{1 m_{1} 1}$ & $X_{1 m_{1} 2}$ & $\ldots$ & $X_{1 m_{1} p}$ \\
& $\vdots$ & $\vdots$ & $\vdots$ & $\vdots$ & $\vdots$ & $\vdots$ \\
Subyek n & 1 & $Y_{n 1}$ & $X_{n 11}$ & $X_{n 12}$ & $\cdots$ & $X_{n 1 p}$ \\
& 2 & $Y_{n 2}$ & $X_{n 21}$ & $X_{n 22}$ & $\ldots$ & $X_{n 2 p}$ \\
& $\vdots$ & $\vdots$ & $\vdots$ & $\vdots$ & $\ldots$ & $\vdots$ \\
& $m_{n}$ & $Y_{n m_{n}}$ & $X_{n m_{n} 1}$ & $X_{n m_{n} 2}$ & $\ldots$ & $X_{n m_{n} p}$ \\
\hline
\end{tabular}




\section{A. Islamiyati, et.al}

\subsection{Multikolinearitas}

Menurut Nurul et.al [14] untuk mendeteksi adanya multikolinearitas pada variabel prediktor yaitu dengan menghitung nilai koefisien korelasi antar variabel predictor. Ukuran korelasi ditunjukkan pada Tabel 2.

Tabel 2. Interpretasi koefisien korelasi

\begin{tabular}{cl}
\hline Nilai & Interpretasi \\
\hline $0,00-0,199$ & Sangat Rendah \\
$0,20-0,399$ & Rendah \\
$0,40-0,599$ & Sedang \\
$0,60-0,799$ & Kuat \\
$0,80-1,000$ & Sangat kuat \\
\hline
\end{tabular}

\subsection{Principal Component Analysis}

Principal Component Analysis bertujuan untuk mereduksi dimensi data asal dilakukan dengan cara menghilangkan korelasi diantara variabel prediktor melalui transformasi variabel prediktor asal ke variabel prediktor baru yang tidak berkorelasi [15]. Komponen utama dapat dibentuk berdasarkan matriks korelasi $(\boldsymbol{R})$ disebabkan karena variabel-variabel prediktor $\boldsymbol{X}=\left[X_{i j 1}, X_{i j 2}, \ldots, X_{i j p}\right]$ yang diamati tidak menggunakan satuan pengukuran yang sama, sehingga perlu disamakan dengan cara mentransformasi ke variabel baku $Z$ [16]. Variabel baku $Z$ diperoleh dari transformasi terhadap variabel asal $X$ yang dirumuskan pada Persamaan (1) berikut:

$$
\begin{gathered}
Z_{i j 1}=\frac{\left(x_{i j 1}-\bar{X}_{1}\right)}{\sqrt{S_{11}}} \\
Z_{i j 2}=\frac{\left(x_{i j 2}-\bar{X}_{2}\right)}{\sqrt{S_{22}}} \\
\vdots \\
Z_{i j p}=\frac{\left(x_{i j p}-\bar{X}_{p}\right)}{\sqrt{S_{p p}}}
\end{gathered}
$$

Menurut Johnson dan Wichern [17], model komponen utama yang dibentuk sebagai kombinasi linear dari variabel yang dibakukan yaitu $\boldsymbol{Z}=\left[Z_{i j 1}, Z_{i j 2}, \ldots, Z_{i j p}\right]$ dengan pasangan nilai eigen dan vektor eigen yaitu $\left(\lambda_{1}, \boldsymbol{\alpha}_{1}\right),\left(\lambda_{2}, \boldsymbol{\alpha}_{2}\right), \ldots,\left(\lambda_{p}, \boldsymbol{\alpha}_{\boldsymbol{p}}\right)$ dengan $\lambda_{1} \geq$ $\lambda_{2} \geq \cdots \geq \lambda_{p}$ dapat dilihat pada Persamaan berikut:

$$
\begin{aligned}
& \boldsymbol{W}_{\boldsymbol{i j 1} \mathbf{1}}=\boldsymbol{\alpha}_{\mathbf{1}}^{\prime} \boldsymbol{Z}=\alpha_{11} Z_{i j 1}+\cdots+\alpha_{1 p} Z_{i j p} \\
& \boldsymbol{W}_{\boldsymbol{i j \mathbf { 2 }} \mathbf{2}}=\boldsymbol{\alpha}_{\mathbf{2}}^{\prime} \boldsymbol{Z}=\alpha_{21} Z_{i j 1}+\cdots+\alpha_{2 p} Z_{i j p} \\
& \quad \vdots \\
& \boldsymbol{W}_{\boldsymbol{i j p}}=\boldsymbol{\alpha}_{\boldsymbol{p}}^{\prime} \boldsymbol{Z}=\alpha_{p 1} Z_{i j 1}+\cdots+\alpha_{p p} Z_{i j p}
\end{aligned}
$$

\subsection{Regresi Data Longitudinal Model Efek Tetap}

Dalam analisis data longitudinal ada 3 model pendekatan yang digunakan yaitu model efek umum, model efek tetap, dan model efek acak. Model efek umum adalah 
pendekatan model regresi data longitudinal yang tidak memperhatikan dimensi individu maupun waktu. Model efek tetap adalah pendekatan model regresi data longitudinal yang mengasumsikan bahwa karakteristik intersep berbeda-beda antar individu tetapi koefisien regresi masing-masing variabel adalah konstan. Model efek acak adalah pendekatan model regresi data longitudinal yang mengasumsikan bahwa setiap individu mempunyai perbedaan intersep, yang mana intersep tersebut adalah variabel acak [13]. Pemodelan data longitudinal yang dilakukan melalui model efek tetap. Adapun bentuk model efek tetap ditampilkan sebagai berikut:

$Y_{i j}=\beta_{0 i}+\beta_{1} X_{i j 1}+\beta_{2} X_{i j 2}+\cdots+\beta_{p} X_{i j p}+\varepsilon_{i j}, i=1,2, \ldots, n, j=1,2, \ldots, m_{i}, k=1,2, \ldots, p$.

\section{Hasil dan Pembahasan}

Langkah awal yang dilakukan sebelum memodelkan gula darah pasien penderita diabetes adalah melakukan statistik deskriptif. Statistik deskriptif bertujuan untuk memberikan informasi awal mengenai variabel yang digunakan dalam penelitian. Statistik deskriptif yang digunakan meliputi nilai rata-rata, minimum, dan maksimum ditampilkan pada Tabel 3.

Tabel 3. Statistik deskriptif variabel penelitian

\begin{tabular}{clllllll}
\hline \multirow{2}{*}{ Variabel } & Statistik & \multicolumn{7}{c}{ Waktu perawatan } \\
\cline { 3 - 8 } & deskriptif & \multicolumn{1}{c}{1} & \multicolumn{7}{c}{2} & \multicolumn{1}{c}{3} & \multicolumn{1}{c}{5} & 6 \\
\hline \multirow{3}{*}{$Y$} & Rata-rata & 266 & 265 & 223 & 227 & 223 & 236 \\
& Minimum & 109 & 127 & 113 & 116 & 100 & 126 \\
& Maksimum & 554 & 480 & 371 & 411 & 411 & 554 \\
\multirow{3}{*}{$X_{1}$} & Rata-rata & 130 & 130 & 125 & 123 & 130 & 130 \\
& Minimum & 110 & 100 & 100 & 100 & 100 & 100 \\
& Maksimum & 160 & 170 & 170 & 170 & 200 & 180 \\
$X_{2}$ & Rata-rata & 82 & 82 & 81 & 81 & 82 & 81 \\
& Minimum & 70 & 70 & 70 & 70 & 70 & 70 \\
& Maksimum & 90 & 100 & 100 & 100 & 100 & 100 \\
$X_{3}$ & Rata-rata & 37 & 37 & 37 & 37 & 37 & 36,90 \\
& Minimum & 36,40 & 36 & 36,40 & 36 & 36,40 & 36 \\
& Maksimum & 38,70 & 38,70 & 38,70 & 38,50 & 38 & 38 \\
$X_{4}$ & Rata-rata & 277.733 & 275.133 & 278.233 & 282.333 & 287.433 & 293.966 \\
& Minimum & 101.000 & 101.000 & 101.000 & 101.000 & 126.000 & 126.000 \\
& Maksimum & 520.000 & 457.000 & 458.000 & 458.000 & 458.000 & 510.000 \\
\hline
\end{tabular}

Tabel 3 menunjukkan bahwa rata-rata variabel gula darah $(Y)$ pasien penderita diabetes dalam enam hari perawatan memiliki gula darah diluar batas normal. Adapun gula darah yang normal sebesar $200 \mathrm{mg} / \mathrm{dL}$. Variabel tekanan darah sistolik $\left(X_{1}\right)$ pasien penderita diabetes dalam enam hari perawatan memiliki rata-rata tekanan darah sistolik diluar batas normal. Adapun tekanan darah sistolik yang normal sebesar $120 \mathrm{mmHg}$. Variabel tekanan darah diastolik $\left(X_{2}\right)$ pasien penderita diabetes dalam enam hari perawatan memiliki rata-rata tekanan darah diastolik diluar batas normal. Adapun tekanan darah diastolik yang normal sebesar $80 \mathrm{mmHg}$. Variabel suhu tubuh $\left(X_{3}\right)$ pasien 


\section{A. Islamiyati, et.al}

penderita diabetes dalam enam hari perawatan memiliki rata-rata suhu tubuh normal, meskipun terdapat beberapa pasien yang memiliki suhu tubuh tinggi. Adapun suhu tubuh yang normal sebesar $36,5^{\circ} \mathrm{C}-37,2^{\circ} \mathrm{C}$. Variabel trombosit $\left(X_{4}\right)$ pasien penderita diabetes dalam enam hari perawatan memiliki rata-rata trombosit normal, meskipun ada beberapa pasien yang memiliki trombosit yang tidak normal. Adapun trombosit yang normal sebesar $150.000 \mathrm{ribu} / \mu \mathrm{L}-450.000 \mathrm{ribu} / \mu \mathrm{L}$.

Selanjutnya, akan dilakukan uji multikolinearitas untuk mengetahui korelasi antar variabel prediktor. Untuk mendeteksi multikolinearitas yang terjadi pada variabel prediktor digunakan matriks korelasi ditampilkan pada Tabel 4.

Tabel 4. Korelasi antar variabel prediktor

\begin{tabular}{ccccc}
\hline Korelasi & $X_{1}$ & $X_{2}$ & $X_{3}$ & $X_{4}$ \\
\hline$X_{1}$ & 1 & 0,871 & 0,236 & $-0,173$ \\
$X_{2}$ & 0,871 & 1 & 0,267 & $-0,243$ \\
$X_{3}$ & 0,236 & 0,267 & 1 & $-0,734$ \\
$X_{4}$ & $-0,173$ & $-0,243$ & $-0,734$ & 1 \\
\hline
\end{tabular}

Tabel 4 menunjukkan bahwa terdapat korelasi yang kuat antar variabel prediktor yaitu variabel tekanan darah sistolik $\left(X_{1}\right)$ dengan variabel tekanan darah diastolik $\left(X_{2}\right)\left(\rho_{1,2}=0,871\right)$. Hal ini menunjukkan bahwa terjadi multikolinearitas pada variabel prediktor sehingga digunakan metode PCA untuk mengatasi masalah tersebut.

Berdasarkan matriks korelasi pada Tabel 4 diperoleh pasangan nilai eigen dan vektor eigen. Nilai eigen dapat menjelaskan besarnya kontribusi keragaman masing-masing komponen utama dalam menjelaskan keragaman data asal. Untuk menentukan jumlah komponen utama yang terbentuk digunakan proporsi variansi kumulatif yang dapat dijelaskan oleh komponen utama. Nilai proporsi variansi kumulatif ditampilkan pada Tabel 5.

Tabel 5. Proporsi variansi dan proporsi variansi kumulatif

\begin{tabular}{cccc}
\hline$W$ & Nilai eigen & Proporsi variansi & Proporsi variansi kumulatif \\
\hline$W_{i j 1}$ & 2,268 & 0,567 & 0,567 \\
$W_{i j 2}$ & 1,340 & 0,335 & 0,902 \\
$W_{i j 3}$ & 0,267 & 0,067 & 0,969 \\
$W_{i j 4}$ & 0,124 & 0,031 & 1,000 \\
\hline
\end{tabular}

Proporsi variansi kumulatif minimal $80 \%$ digunakan untuk menentukan komponen utama yang terbentuk [17]. Tabel 5 menunjukkan bahwa ada dua komponen utama dapat menjelaskan proporsi variansi kumulatif sebesar 90,2\%. Adapun kombinasi linear dari dua komponen utama yaitu komponen utama pertama dan komponen utama kedua sebagai berikut:

$$
\begin{aligned}
& W_{i j 1}=-0,524 Z_{i j 1}-0,546 Z_{i j 2}-0,473 Z_{i j 3}+0,450 Z_{i j 4} \\
& W_{i j 2}=0,484 Z_{i j 1}+0,439 Z_{i j 2}-0,516 Z_{i j 3}+0,554 Z_{i j 4}
\end{aligned}
$$

dengan $i=1,2, \ldots, 30$ dan $j=1,2, \ldots, 6_{i}$ 
Persamaan 4 menunjukkan pengaruh variabel prediktor yang berbeda pada setiap komponen. Selanjutnya, Persamaan (4) digunakan untuk mencari nilai atau score dari kedua komponen utama pasien diabetes. Berdasarkan nilai atau score komponen utama yang diperoleh, selanjutnya digunakan untuk memodelkan regresi data longitudinal PCA dengan model efek tetap.

Model efek tetap yang terbentuk dari proses PCA dapat ditunjukkan sebagai berikut:

$$
\hat{Y}_{i j}=\hat{\beta}_{0 i}+0,189\left(W_{i j 1}\right)-0,063\left(W_{i j 2}\right)
$$

Nilai intersep untuk masing-masing pasien penderita diabetes di RS. Ibnu Sina Kota Makassar seperti pada Tabel 6.

Tabel 6. Intersep masing-masing pasien penderita diabetes

\begin{tabular}{cccr}
\hline Pasien $\mathrm{ke}-i$ & $\hat{\beta}_{0 i}$ & Pasien $\mathrm{ke}-i$ & \multicolumn{1}{c}{$\hat{\beta}_{0 i}$} \\
\hline 1 & 0,523 & 16 & $-0,942$ \\
2 & 0,835 & 17 & 0,724 \\
3 & 0,140 & 18 & 0,053 \\
4 & 1,187 & 19 & $-0,320$ \\
5 & $-0,149$ & 20 & 0,533 \\
6 & $-0,640$ & 21 & $-0,380$ \\
7 & 0,209 & 22 & $-0,829$ \\
8 & $-0,169$ & 23 & 0,046 \\
9 & 0,252 & 24 & $-0,903$ \\
10 & $-0,406$ & 25 & -0.179 \\
11 & 0,806 & 26 & 0,719 \\
12 & 0,284 & 27 & 0,084 \\
13 & $-0,620$ & 28 & $-0,901$ \\
14 & 0,088 & 29 & $-0,255$ \\
15 & $-0,121$ & 30 & 0,332 \\
\hline
\end{tabular}

Komponen utama pertama $\left(W_{i j 1}\right)$ dan komponen utama kedua $\left(W_{i j 2}\right)$ pada Persamaan (5) ditransformasi ke variabel asal. Jika Persamaan (4) disubstitusikan ke dalam Persamaan (5), maka diperoleh model sebagai berikut:

$$
\hat{Y}_{i j}=\hat{\beta}_{0 i}-0,007 X_{i j 1}-0,016 X_{i j 2}-0,098 X_{i j 3}+0,005 X_{i j 4}
$$

Nilai intersep masing-masing pasien penderita diabetes kemudian ditransformasi ke variabel asal seperti pada Tabel 7.

Tabel 7. Intersep hasil transformasi ke variabel asal

\begin{tabular}{cccc}
\hline Pasien ke- $i$ & $\hat{\beta}_{0 i}{ }^{*}$ & Pasien ke-i & $\hat{\beta}_{0 i}{ }^{*}$ \\
\hline 1 & $-83,222$ & 16 & $-84,688$ \\
2 & $-82,910$ & 17 & $-83,022$ \\
3 & $-83,605$ & 18 & $-83,693$ \\
4 & $-82,559$ & 19 & $-84,066$ \\
5 & $-83,894$ & 20 & $-83,213$ \\
6 & $-84,385$ & 21 & $-84,126$ \\
7 & $-83,536$ & 22 & $-84,574$ \\
8 & $-83,914$ & 23 & $-83,700$ \\
\hline
\end{tabular}




\section{A. Islamiyati, et.al}

Tabel 7. Intersep hasil transformasi ke variabel asal

\begin{tabular}{cccc}
\hline Pasien ke $-i$ & $\hat{\beta}_{0 i}{ }^{*}$ & Pasien ke-i & $\hat{\beta}_{0 i}{ }^{*}$ \\
\hline 9 & $-83,493$ & 24 & $-84,649$ \\
10 & $-84,152$ & 25 & $-83,924$ \\
11 & $-82,940$ & 26 & $-83,027$ \\
12 & $-83,462$ & 27 & $-83,661$ \\
13 & $-84,366$ & 28 & $-84,646$ \\
14 & $-83,657$ & 29 & $-84,000$ \\
15 & $-83,866$ & 30 & $-83,413$ \\
\hline
\end{tabular}

Persamaan (6) merupakan model gula darah pasien diabetes yang diperoleh dari 2 komponen utama yang terbentuk dari suatu analisis data longitudinal. Model menunjukkan bahwa pengaruh paling besar diberikan oleh faktor tekanan darah diastolik. Akan tetapi, jika dihubungkan dengan hasil analisis komponen utama, maka ada dua komponen yang dapat saja terjadi pada gula darah penderita diabetes.

\section{Kesimpulan}

Berdasarkan hasil yang diperoleh, model gula darah pasien penderita diabetes menggunakan metode principal component analysis melalui model efek tetap yang digunakan pada penelitian ini. Adapun model yang terbentuk sebagai berikut:

$$
\hat{Y}_{i j}=\hat{\beta}_{0 i}+0,189\left(W_{i j 1}\right)-0,063\left(W_{i j 2}\right)
$$

Model hasil transformasi PCA ke variabel asal sebagai berikut:

$$
\hat{Y}_{i j}=\hat{\beta}_{0 i}-0,007 X_{i j 1}-0,016 X_{i j 2}-0,098 X_{i j 3}+0,005 X_{i j 4}
$$

Berdasarkan model gula darah pasien penderita diabetes dengan metode PCA longitudinal efek tetap, diperoleh dua komponen utama yang mampu menjelaskan proporsi variansi sebesar 90,2\%. Kedua komponen utama yang terbentuk menunjukkan ada dua komponen pengaruh dari setiap predictor, yaitu variabel tekanan darah sistolik $\left(\mathrm{X}_{1}\right)$, variabel tekanan darah diastolik $\left(\mathrm{X}_{2}\right)$, variabel suhu tubuh $\left(\mathrm{X}_{3}\right)$, dan variabel trombosit $\left(\mathrm{X}_{4}\right)$ terhadap gula darah pasien diabetes.

\section{Referensi}

[1] P. I. G. D. I. Putra, P. A. I. Wirawati, dan N. N. Mahartini, "'Hubungan Kadar Gula Darah dengan Hipertensi Pada Pasien Diabetes Melitus Tipe 2 di RUSP Sanglah," Directory of Open Access Journals., vol. 10, no. 3, 2019.

[2] Kemenkes, Infodatin Pusat Data dan Informasi Kementerian Kesehatan RI, Jakarta: Kementerian Kesehatan Republik Indonesia, 2020.

[3] RISKESDAS, Laporan Provinsi Sulawesi Selatan RISKESDAS 2018, Jakarta: Badan Penelitian dan Pengembangan Kesehatan, 2019.

[4] Z. A. Ramdhani, A. Islamiyati dan R. Raupong, "Hubungan Faktor Kolestrol Terhadap Gula Darah Diabetes dengan Spline Kubik Terbobot," Jurnal Estimasi., vol.1, no.1, 2020. 
[5] D. R. Ente, A. Islamiyati, dan R. Raupong, "Pengaruh Indeks Massa Tubuh dan Trigliserida Terhadap Gula Darah dengan Model Regresi Nonparametrik Spline Bipreditor," Jurnal Estimasi., vol. 2, no. 2, 2021.

[6] A. Islamiyati, F. Fatmawati and N. Chamidah, "Changes in blood glucose 2 hours after meals in Type 2 diabetes patients based on length of treatment at Hasanuddin University Hospital, Indonesia," Rawal Medical Journal., vol. 45, no. 1, 2020.

[7] I. Ana, "Analisis Metode Principal Component Analysis (Komponen Utama) dan Regresi Ridge dalam Mengatasi Dampak Multikolinearitas dalam Analisis Regresi Linier Berganda," Matematika dan Ilmu Pengetahuan Alam, Universitas Negeri Semarang, 2011

[8] Soemartini, "Principal Component Analysis (PCA) Sebagai Satu Metode untuk Mengatasi Masalah Multikolinearitas," Matematika dan Ilmu Pengetahuan Alam, Universitas Padjajaran, Jatinangor, 2008.

[9] M. Gresyea L, W. Henry J, dan L. Yopi A, "Analisis Regresi Komponen Utama Untuk Mengatasi Masalah Multikolinieritas Dalam Analisis Regresi Linear Berganda," BAREKENG: Jurnal Ilmu Matematika dan Terapan., vol. 6, no. 1, 2012.

[10] D. M. S. N. Van, W. Abraham Z, dan S. Susanti, "Penggunaan Metode Analisis Komponen Utama untuk Mereduksi Faktor-Faktor Inflasi di Kota Ambon," Jurnal Ilmu Matematika dan Terapan., vol. 11, no. 2, 2017.

[11] Y. Safaat dan P. Ully, "Analisis Komponen Utama untuk Pengelompokan Area Pelayanan dan Jaringan Daerah Jawa Tengah dan D.I. Yogyakarta," Jurnal Jasdm., vol. 1, no. 1, 2019.

[12] D. Peter, H. Patrick., L. K. Yee, and Z. Scott, Analysis of Longitudinal Data, Second Edition. Oxford: Oxford University Press, 2013.

[13] G. Muhammad dan O. W. Bambang, "Pemodelan Fixed Effect Pada Regresi Data Longitudinal dengan Estimasi Generalized Method of Moments (Studi Kasus Data Penduduk Miskin di Indonesia)," Jurnal Statistika., vol. 9, no. 1, 2016.

[14] F. Nurul, Mawardi, dan K. A. Rizmahardian,"'Korelasi Keterampilan Metakognisi dengan Aktivitas dan Hasil Belajar Siswa," Ar-Razi Jurnal Ilmiah., vol. 5, no. 1, 2017.

[15] J. I. T, Principal Component Analysis, New York: Springer-Verlag New York, Inc, 2002.

[16] S. Arifin, A. Islamiyati, dan R. Raupong, "Kemampuan Estimator Spline Linier Dalam Analisis Komponen Utama," Jurnal Estimasi., vol. 1, no. 1, 2020.

[17] R. A. Johnson and D. W. Wichern, Applied Multivariate Statistical Analysis, Sixth Edition. New Jersey: Printice Hall of India Private Limited, 2007.

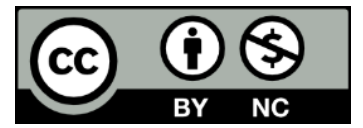

This article is an open-access article distributed under the terms and conditions of the Creative Commons Attribution-NonCommercial 4.0 International License. Editorial of JJoM: Department of Mathematics, Universitas Negeri Gorontalo, Jln. Prof. Dr. Ing. B.J. Habibie, Moutong, Tilongkabila, Kabupaten Bone Bolango, Provinsi Gorontalo 96119, Indonesia. 